IT has been shown that Botbrops jararaca venom (BjV) induces a significant leukocyte accumulation, mainly neutrophils, at the local of tissue damage. Therefore, the role of the adhesion molecules intercellular adhesion molecule-1 (ICAM-1), LECAM-1, CD18, leukocyte function-associated antigen-1 (LFA1) and platelet endothelial cell adhesion molecule-1 (PECAM-1) on the BjV-induced neutrophil accumulation and the correlation with release of LTB4, TXA2, tumor necrosis factor- $\alpha$, interleukin (IL)-1 and IL-6 have been investigated. Anti-mouse LECAM-1, LFA-1, ICAM-1 and PECAM-1 monoclonal antibody injection resulted in a reduction of $42 \%, 80 \%, 66 \%$ and $67 \%$, respectively, of neutrophil accumulation induced by BjV $(250 \mu \mathrm{g} / \mathrm{kg}$, intraperitoneal $)$ injection in male mice compared with isotype-matched control injected animals. The anti-mouse CD18 monoclonal antibody had no significant effect on venom-induced neutrophil accumulation. Concentrations of $\mathbf{L T B}_{4}$, TXA $_{2}$, IL- 6 and TNF- $\alpha$ were significant increased in the peritoneal exudates of animals injected with venom, whereas no increment in IL-1 was detected. This results suggest that ICAM-1, LECAM-1, LFA-1 and PECAM-1, but not CD18, adhesion molecules are involved in the recruitment of neutrophils into the inflammatory site induced by $\mathrm{BjV}$. This is the first in vivo evidence that snake venom is able to up-regulate the expression of adhesion molecules by both leukocytes and endothelial cells. This venom effect may be indirect, probably through the release of the inflammatory mediators evidenced in the present study.

Key words: Snake venom, Adhesion molecules, Cytokines, Eicosanoids, Leukocyte influx

\section{Cell adhesion molecules involved in the leukocyte recruitment induced by venom of the snake Bothrops jararaca}

\author{
Stella R. Zamuner and Catarina F. P. Teixeira ${ }^{\text {CA }}$
}

Laboratory of Pharmacology, Butantan Institute, Av. Vital Brazil 1500, São Paulo, SP CEP 05504-900, Brazil

${ }^{\mathrm{CA}}$ Corresponding Author:
Fax: +55 1137261505
E-mail: cteixeir@usp.br

\section{Introduction}

The snake Bothropos jararaca is responsible for most snakebite accidents in Brazil. Its venom induces severe pathophysiological effects characterized by local tissue damage, with hemorrhage, pain, myonecrosis and inflammation. ${ }^{1-3}$ Several studies demonstrate that Bothrops venoms induce a significant leukocyte accumulation at the site of inflammation. ${ }^{4-6}$ However, the mechanisms involved in this event have not been elucidated. Leukocyte accumulation in inflamed tissue results from generation of chemotactic factors as well as adhesive interactions between leukocytes and endhotelial cells within the microcirculation. ${ }^{7}$

Leukocyte recruitment into inflammatory sites is known to be a multi-step process, which is characterized by an initial transient contact with the endothelium, or rolling, followed by firm adhesion and transmigration. ${ }^{89}$ The initial phase of the adhesion cascade, neutrophil rolling, is mediated by members of the selectin family (L-selectin on neu- trophils, and P-selectin and E-selectin on endothelial cells). Next, intercellular adhesion molecule-1 (ICAM1) (CD54), which belongs to the immunoglobulin superfamily, binds to leukocyte function-associated antigen-1 (LFA-1) (CD11/CD18) on leukocytes. ${ }^{10}$ This interaction results in arrest and firm adhesion of the neutrophil to the endothelium, and is required for transendothelial cell migration. ${ }^{11}$ Finally, platelet endothelial cell adhesion molecule-1 (PECAM-1) (CD31) is required for the activation of proteases needed for passage through endothelial junctions and/or the basement membrane. ${ }^{12,13}$ Each adhesion molecules is involved in a different phase of leukocyte emigration through the endothelium, and the synchronization of their expression and functions is crucial for recruitment of leukocytes from the bloodstream to the tissue. ${ }^{14} \mathrm{~A}$ range of inflammatory mediators regulates this cascade by a sequential release. $^{15}$

In the present study we investigated the importance of some adhesion molecules (ICAM-1, LFA-1, PECAM-1, LECAM-1 and CD18 $\beta_{2}$-integrin) in the 
migration of neutrophils into the peritoneum after injection of $B$. jararaca venom in mice and the release of some inflammatory cytokines and eicosanoids. Understanding the mechanisms of venominduced cell influx will be helpful for the pharmacological modulation of inflammatory events associated with Bothrops venom-induced local injury.

\section{Materials and methods}

\section{Chemicals and reagents}

Heparin was obtained from Roche (Rio de Janeiro, Brazil). Murine capture antibody anti-IL-6 (clone MP5-20F3), recombinant IL-6 and detection antibody anti-IL-6 (clone MP5-32C11) were purchased from Pharmingen (CA, USA). Rat monoclonal antibodies directed against L-selectin (anti-mouse CD62L, clone MEL-14), ICAM-1 (anti-mouse CD54, clone 3E2), LFA1- $\alpha$ chain (anti-mouse CD11a, clone M17/4), PECAM-1 (anti-mouse CD31, clone MEC 13.3), $\beta_{2}$-integrin $\beta$ chain (anti-mouse CD18, clone GAME 46) were purchased from Pharmingen. Rat immunoglobulin (Ig)G anti-horse IgG (irrelevant antibody) derived from mouse myeloma (ascitic fluid) was kindly provided by Dr Irene Fernandes (Immunopathology Laboratory, Butantan Institute, São Paulo, Brazil). 2,2'-Azino-bis(3 ethylbenzthiazoline-6-sulfonic acid) ABTS was purchased from Southern Biotechnology Associates Inc. (AL, USA). All salts used were obtained from Merck (Darmstadt, Germany).

\section{Venom}

Lyophilized crude venom of $B$. jararaca $(\mathrm{BjV})$ was supplied by the Herpetology Laboratory of Butantan Institute. The venom was dissolved in $0.15 \mathrm{M} \mathrm{NaCl}$ solution and subsequently filtered through sterilizing membranes $(0.22 \mu \mathrm{m}$ pore size; Millipore Ind. Com. Ltd, Brazil) before use.

\section{Animals}

Male Swiss mice (18-20 g) were used. These animals were housed in temperature-controlled rooms and received water and food ad libitum until used. These studies were approved by the Experimental Animals Committee of Butantan Institute (protocol number 014/2001) in accordance with the procedures laid down by the Universities Federation for Animal Welfare.

\section{Induction of inflammatory reaction}

$\mathrm{BjV}(250 \mu \mathrm{g} / \mathrm{kg})$, dissolved in $1 \mathrm{ml}$ of sterile saline was injected by the intraperitoneal (i.p.) route. Control animals received $1 \mathrm{ml}$ of sterile saline alone.
At selected time intervals, the animals were killed under a halothane atmosphere and the inflammatory exudate was withdrawn after washing the cavities with $2 \mathrm{ml}$ of phosphate-buffered saline (PBS) ( $\mathrm{pH}$ 7.2). Aliquots of the washes were used to determine total cell counts. The remaining volume was centrifuged at $500 \times g$ for $6 \mathrm{~min}$ (at $4^{\circ} \mathrm{C}$ ), and supernatants were stored at $-70^{\circ} \mathrm{C}$ and later used for the determination of eicosanoids or cytokine concentration.

\section{Leukocyte harvesting and counting}

Leukocytes were harvested $6 \mathrm{~h}$ after i.p. injection of $\mathrm{BjV}$ or sterile saline by washing peritoneal cavities with $2 \mathrm{ml}$ of PBS containing heparin $(10 \mathrm{U} / \mathrm{ml})$. Aliquots of the washes were used to determine total cell counts in a Neubauer chamber after dilution $(1: 20, v / v)$ in Turk solution $(0.2 \%$ crystal violet dye in $30 \%$ acetic acid). For differential cells counts, cytospin preparations were stained with $\mathrm{Hema}^{3}$ stain (Biochemical Sciences Inc.). Differential cell counts were performed by counting at least 100 cells, which were classified as either polymorphonuclear or mononuclear cells, based on conventional morphological criteria.

\section{Treatment with anti-adhesion molecules}

Groups of mice were injected intravenously (i.v.), in the tail vein, with antibodies against adhesion molecules $(1 \mathrm{mg} / \mathrm{kg}){ }^{16}$ Control animals received a similar injection of either saline solution or an equivalent dose of control rat IgG monoclonal antibody (mAb (LO-HoGa-3I), which recognizes horse $\operatorname{IgG(T)} .^{17}$ After $30 \mathrm{~min}$, mice were injected i.p. with $\mathrm{BjV}$ $(250 \mu \mathrm{g} / \mathrm{kg})$, and the neutrophil influx was assessed at $6 \mathrm{~h}$, as already described.

\section{Quantification of eicosanoid concentrations}

Concentrations of $\mathrm{LTB}_{4}$ and $\mathrm{TXB}_{2}$ (stable metabolite of $\mathrm{TXA}_{2}$ ) were measured in the peritoneal washes at 30,60 and $240 \mathrm{~min}$ after i.p. injections of $\mathrm{BjV}$ $(250 \mu \mathrm{g} / \mathrm{kg})$ or sterile saline, by a specific enzymatic immunoassay (EIA) previously described by Pradelles et al. ${ }^{18}$ using a commercial kit (Cayman Chemicals, MI, USA), after extraction of eicosanoids on Sep Pak C18 columns eluted with ethanol. In brief, $100 \mu 1$ aliquots of each extracted sample were incubated with the eicosanoids conjugated with acetylcholinesterase and the specific rabbit antiserum, in 96-well microtitration plates coated with anti-rabbit IgG mouse monoclonal antibody. After addition of the substrate, the absorbances of the samples were recorded at $412 \mathrm{~nm}$ in a microplate reader, and the concentration of the eicosanoids was estimated from standard curves. 


\section{Quantification of IL-6 or IL-1 $\alpha$ concentrations}

Peritoneal washes were collected 30, 60, 180 and $360 \mathrm{~min}$ after i.p. injection of $\mathrm{BjV}(250 \mu \mathrm{g} / \mathrm{kg})$ or saline. After centrifugation, the supernatants were used for determination of IL- 6 and IL- $1_{\alpha}$ levels by a specific EIA, as described by Schumaker et al. ${ }^{19}$ Briefly, 96-well plates were coated with $50 \mu 1$ of the first capture monoclonal antibody (anti-IL-6, $2.5 \mu \mathrm{g} / \mathrm{ml}$; or anti $\mathrm{IL}-1_{\alpha}, 2 \mu \mathrm{g} / \mathrm{ml}$ ) and incubated overnight at room temperature. Then $200 \mu 1$ of blocking buffer, containing PBS/Tween-milk 5\%, were added to the wells and the plates incubated for $2 \mathrm{~h}$ at room temperature. After washing, $50 \mu 1$ of either samples or standards were dispensed into each well and the plates incubated for $2 \mathrm{~h}$ at room temperature. Wells were washed, and bound IL- 6 or IL- $1_{\alpha}$ was detected by the addition of the biotinylated anticytokine monoclonal antibody $(5 \mu \mathrm{g} / \mathrm{ml}, 50 \mu \mathrm{l} /$ well). After incubation and washing, $50 \mu 1$ of avidin-phosphatase or peroxidase-labeled streptavidin were added, followed by incubation and addition of the substrate $(200 \mu 1 / \mathrm{ml}$ of $p$-nitrophenylphosphate or $50 \mu 1 / \mathrm{ml}$ of $o$-phenyldianizidine) for IL-6 or IL- $1_{\alpha}$ detection, respectively. Absorbances at $450 \mathrm{~nm}$ were recorded and plotted against a standard curve prepared with recombinant IL- 6 or IL- $1_{\alpha}$ in order to determine the concentration of this cytokine.

\section{Quantification of TNF- $\alpha$ concentrations}

Peritoneal washes were collected $30 \mathrm{~min}$, and 1, 3 and $6 \mathrm{~h}$ after i.p. injection of $\mathrm{BjV}(250 \mu \mathrm{g} / \mathrm{kg})$ or saline. After centrifugation, the cells were used for determination of TNF- $\alpha$ levels by a standard assay using the fibroblast continuous cell line L-929, as described by Ruff and Gifford. ${ }^{20}$ Monolayers of L-929 cells grown in RPMI- 1640 medium were seeded at $3.5 \times 10^{4}$ cells per well in microtiter plates and incubated in humidified air with $5 \% \mathrm{CO}_{2}$ at $37^{\circ} \mathrm{C}$ for $18 \mathrm{~h}$. Afterwards, $100 \mu 1$ of the samples containing $2.5 \times$ $10^{4}$ peritoneal cells were added serially and $0.2 \mu \mathrm{g} /$ well of the anti-TNF- $\alpha$ was added for the determination of the assay specificity. The plates were incubated during $4 \mathrm{~h}$, and actinomycin $\mathrm{D}(2 \mu \mathrm{g} / \mathrm{ml})$ was then added. After incubation for $18 \mathrm{~h}$ at $37^{\circ} \mathrm{C}$, supernatants were removed and viable cells were assessed after fixation and staining with crystal violet ( $0.2 \%$ in $20 \%$ methanol). Cytotoxicity, expressed as a percentage, was calculated as follow (Abs control $_{\text {- }}$ $\left.\mathrm{Abs}_{\text {sample }} / \mathrm{Abs}_{\text {control }}\right) \times 100$. TNF- $\alpha$ levels were then expressed as picograms per milliter, using a standard curve prepared with recombinant $\mathrm{TNF}^{-} \alpha$.

\section{Statistical analysis}

Means and SEM of all data were obtained and compared by analysis of variance followed by the

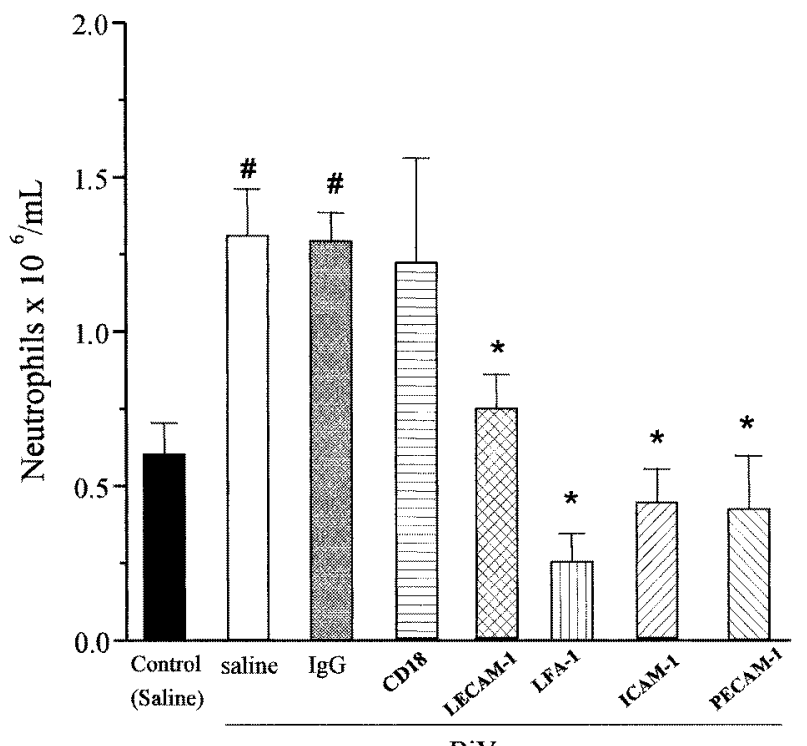

BjV

FIG. 1. The effect of anti-murine adhesion molecules on the mAbs on the recruitment of peritoneal neutrophils after administration of $\mathrm{BjV}$. Mice were pre-treated i.v. with $1 \mathrm{mg} / \mathrm{kg}$ of the indicated $\mathrm{mAb}$, rat normal IgG or saline $30 \mathrm{~min}$ before i.p. injection of $\mathrm{BjV}(250 \mu \mathrm{g} / \mathrm{kg})$. Peritoneal cells were harvested and counted $6 \mathrm{~h}$ after envenomation. A negative control group of animals received an i.v. injection of saline. Data represent the mean \pm SEM of at least four mice in each group. \# $p<0.05$ compared with control (saline), ${ }^{*} p<0.05$ compared with $\mathrm{BjV}$ or $\mathrm{BjV}+$ normal rat IgG.

Tukey test, with significance probability levels of $p<0.05$.

\section{Results}

\section{Effect of treatment with mAbs against adhesion molecules on neutrophil influx}

To test whether adhesion molecules play a critical role on BjV-induced neutrophil in vivo, the effect of neutralizing mAbs against several adhesion molecules was examined. Since maximal neutrophil influx was observed $6 \mathrm{~h}$ after venom injection, ${ }^{3}$ we evaluated these mAbs on neutrophil accumulation at this time point. As shown in Fig. 1, i.v. injection of saline followed by i.p. injection of $\mathrm{BjV}(5 \mu \mathrm{g} /$ mouse $)$ caused accumulation of $(1.3 \pm 0.1) \times 10^{6}$ neutrophils at $6 \mathrm{~h}$. Intravenous administration of mAbs anti-ICAM-1, anti-LECAM-1, anti-LFA-1 and anti-PECAM-1 ( $200 \mu \mathrm{g} /$ mouse) $30 \mathrm{~min}$ before the i.p. injection of the $\mathrm{BjV}$ significantly reduced the number of recovered neutrophils to $(0.44 \pm 0.11) \times 10^{6},(0.75 \pm 0.15) \times 10^{6}$, $(0.26 \pm 0.09) \times 10^{6}$ and $(0.43 \pm 0.17) \times 10^{6}$ neutrophils, respectively $(p<0.05$, compared with $\mathrm{BjV}$ ), a response that was not significantly different from that seen after i.p. injection of saline $[(0.6 \pm 0.1)$ $\times 10^{6}$ neutrophils]. In contrast, anti-CD18 mAbs did not inhibit neutrophils infiltration. 

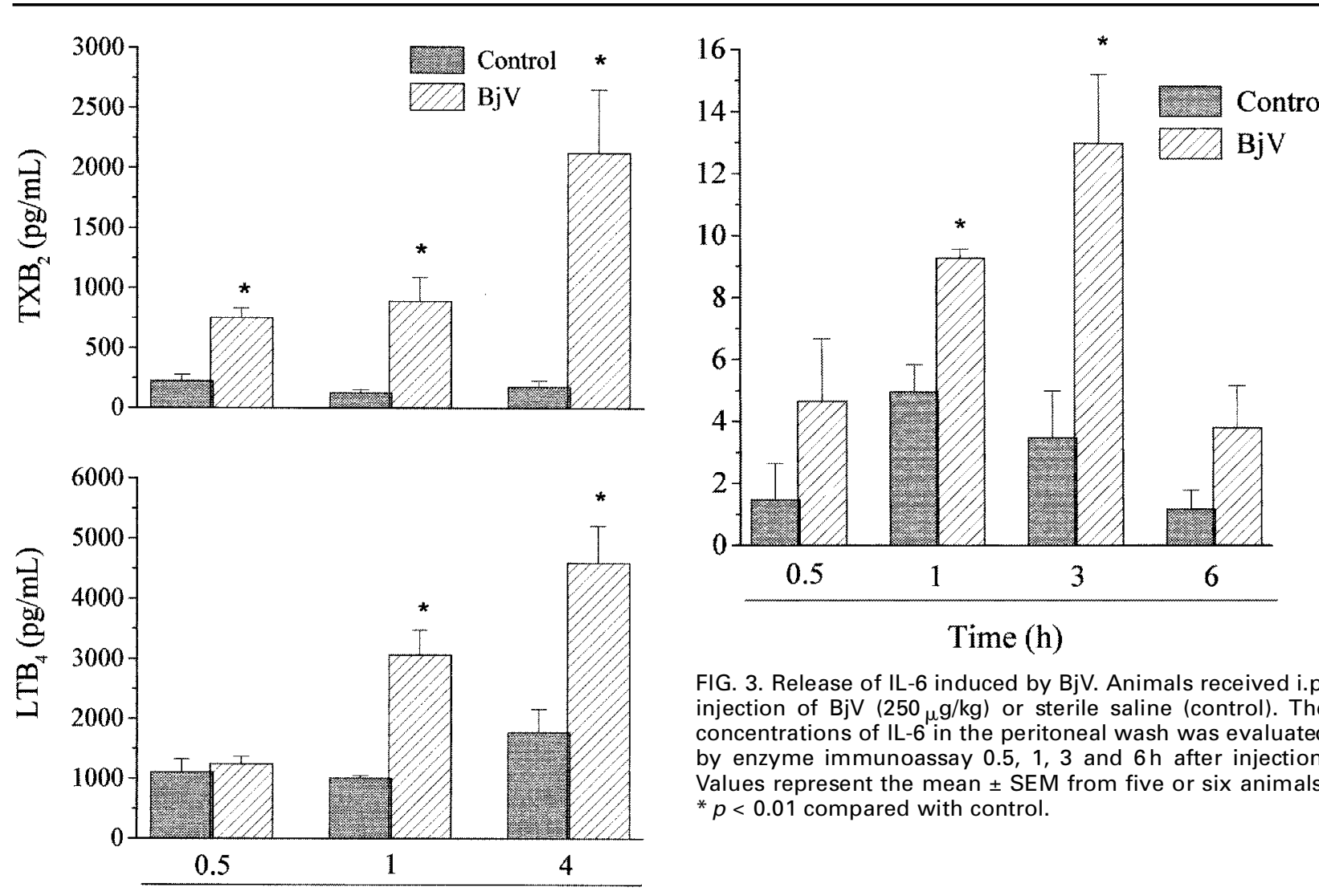

\section{Time (h)}

FIG. 3. Release of IL-6 induced by BjV. Animals received i.p. injection of BjV $(250 \mu \mathrm{g} / \mathrm{kg})$ or sterile saline (control). The concentrations of IL- 6 in the peritoneal wash was evaluated by enzyme immunoassay $0.5,1,3$ and $6 \mathrm{~h}$ after injection. Values represent the mean \pm SEM from five or six animals. ${ }^{*} p<0.01$ compared with control.

\section{Time (h)}

FIG. 2. $\mathrm{LTB}_{4}$ and $\mathrm{TXB}_{2}$ concentration in the peritoneal exudate after BjV injection. Groups of animals were injected i.p. with $B j V(250 \mu \mathrm{g} / \mathrm{kg})$ or sterile saline (control). Concentration of $\mathrm{LTB}_{4}$ and TXB 2 was evaluated by specific EIA in peritoneal washes collected 30,60 and 240 min after injection. Each bar represents the mean \pm SEM from four animals. * $p<0.05$ compared with control.

\section{Changes in peritoneal exudate eicosanoid and cytokine release}

To investigate the ability of of $\mathrm{BjV}$ to release chemotactic mediators in the peritoneal cavity of mice, the concentrations of $\mathrm{LTB}_{4}$ and $\mathrm{TXA}_{2}$ in the peritoneal fluids of these animals were measured. $\mathrm{BjV}$ $(250 \mu \mathrm{g} / \mathrm{kg})$ induced a marked increase in peritoneal $\mathrm{TXB}_{2}$ levels between 30 and $240 \mathrm{~min}$. $\mathrm{LTB}_{4}$ was significantly increased between 60 and $240 \mathrm{~min}$ (Fig. 2).

To further analyze the mechanisms of the inflammatory events induced by $\mathrm{BjV}$, the concentrations of IL- 6 , IL- $1_{\alpha}$ and TNF- $\alpha$ in the peritoneal fluid were measured. $\mathrm{BjV}$ induced a rapid elevation of IL-6 levels in the peritoneal exudate, peaking $3 \mathrm{~h}$ after the injection of the venom, and returning to normal values at $6 \mathrm{~h}$ (Fig. 3). The peak concentration was $14.5 \mathrm{ng} / \mathrm{ml}$ and control value was $5 \mathrm{ng} / \mathrm{ml}$. No detectable levels of IL$1_{\alpha}$ were observed in the peritoneal exudates collected after the injection of $\mathrm{BjV}$ (data not shown).

The venom significantly induced a marked increment of $\mathrm{TNF}_{-}$levels at all time intervals analyzed,

except at $3 \mathrm{~h}$. An early increase was observed $30 \mathrm{~min}$ after $\mathrm{BjV}$ injection, with maximum levels at $1 \mathrm{~h}(580 \%$ increment when compared with levels in control mice) (Fig.4).

\section{Discussion}

Neutrophils migrate from vessels in response to a stimulus at the inflammatory site. The onset of



FIG. 4. Release of $\mathrm{TNF}_{-\alpha}$ induced by $\mathrm{BjV}$ in the peritoneal cavity of mice. Animals were injected i.p. with BjV $(250 \mu \mathrm{g} / \mathrm{kg})$ or sterile saline (control). Concentrations of TNF$\alpha$ were assayed by cytotoxic activity on L929 cells. Each value represents the mean \pm SEM from five to seven animals. ${ }^{*} p<0.05$ compared with control. 
inflammation results in increased expression, or altered avidity of adhesion molecules, and thus increases in the adhesiveness of both the circulating cells and the endothelium. ${ }^{15}$

The involvement of LECAM-1, ICAM-1, LFA-1, PECAM-1 and CD18 adhesion molecules in the leukocyte influx into the peritoneal cavity of mice after injection of $\mathrm{BjV}$ was investigated by pre-treating animals with selected anti-adhesion molecule mAbs. Previous results from our laboratory showed a significant accumulation of PMN cells into the peritoneal cavity of mice up to $24 \mathrm{~h}$ following $\mathrm{BjV}$ injection, with maximal counts of neutrophils between 3 and $12 \mathrm{~h}^{3}$

Present data showed that the anti-mouse LECAM$1 \mathrm{mAb}$ significantly reduced the neutrophil migration. LECAM-1 is constitutively expressed on the neutrophil and is shed from the cell surface on cell activation, contributing to neutrophil rolling at the initial phase of the adhesion cascade. ${ }^{21}$ Thus, the obtained data suggest that $\mathrm{Bj} \mathrm{V}$ induces the expression of this leukocyte adhesion molecule from the selectin family that mediates rolling events. Previous reports have shown that L-selectin participates in leukocyte rolling after tissue trauma. ${ }^{22}$

The expression of selectin adhesion molecules in leukocytes does not lead to firm adhesion and transmigration unless another set of adhesion molecules is engaged. For neutrophils, firm adhesion requires activation of the $\beta_{2}(C D 18)$ adhesion molecule from the integrin family, resulting in binding to one of the intercellular adhesion molecules at the surfaces of endothelial cells. ${ }^{23}$ Results showed that anti-mouse LFA-1 (CD11a/CD18) mAb strongly inhibited the cell influx in our model. This further indicates the ability of the $\mathrm{BjV}$ to activate neutrophils to express adhesion molecules, in this case an integrin that is relevant for the firm adhesion of leukocytes. Conversely, no inhibitory effect of anti-CD $18 \mathrm{mAb}$ on neutrophil migration was observed. This result is unexpected because the literature shows that blockingmAbs directed against CD18 are effective inhibitors of neutrophil migration in various inflammatory models in vivo. ${ }^{15}$ However, CD18-independent mechanisms of cell adhesion are also known to exist ${ }^{24,25}$ and it is well established that CD18-independent neutrophil migration occurs in pulmonary inflammation in numerous animal species. ${ }^{26,27}$ In addition, Winn and Harlan $^{28}$ have described a CD18-independent neutrophil migration into the peritoneum of rabbits due to release of a factor by macrophage already present at the inflammatory site. However, we cannot discard the contribution of $\mathrm{CD} 18$ on $\mathrm{BjV}$-induced neutrophil influx in other time intervals that were not evaluated in this study. It is possible that, at the period of time used to analyze the influx of neutrophils $(6 \mathrm{~h})$, the increased expression of other adhesion molecules could overcome the blockade of CD18, a hypothesis that needs to be further addressed.
In addition, we observed that venom-elicited peritoneal neutrophil influx was inhibited by both antiICAM-1 and anti-PECAM-1 mAbs. These results suggest that ICAM-1 and PECAM-1 may be required for the venom-induced trafficking of neutrophils and indicate the ability of $\mathrm{BjV}$ to activate the endothelium, since these molecules are expressed by endothelial cells. ${ }^{29}$ ICAMs are ligands for the integrin molecules LFA-1 and MAC-1 on leukocytes. ${ }^{10}$ ICAM-1 participates in leukocyte-leukocyte, leukocyte-endothelial, and leukocyte-epithelial cell interations, transendothelial migration, and adhesion-dependent respiratory burst. ${ }^{30}$ Thus, in the present experimental conditions, ICAM-1 may be the ligand for LFA-1 and both molecules may contribute to neutrophIL-endothelial interactions.

PECAM-1 is one of the most abundant proteins on the endothelial cell surface. It is located at the cellcell borders of adjacent endothelial cells and plays an important role in transendothelial migration of neutrophils. ${ }^{31}$ PECAM-1 is important in the passage of neutrophils through endothelial junctions mainly in cytokine-activated transmigration; it seems to have little role in the chemotactic transmigration. ${ }^{13}$ Taking into account that large accumulation of neutrophils occurs at $6 \mathrm{~h}$, we suggest that the venom may trigger a cytokine-activated transmigration process leading to the passage of neutrophils across endothelium and into the tissues. Our results, however, do not rule out the possibility that a chemotactic-dependent or a PECAM-1-independent mechanism may also operate in the passage of leukocyte through the endothelial cell junctions at the early stages of inflammatory response to the venom. To our knowledge this is the first report dealing with characterization of the adhesion molecules involved in the leukocyte influx induced by snake venoms.

It is well known that $\mathrm{LTB}_{4}$ and $\mathrm{TXA}_{2}$ induce the expression of ICAM-1 and PECAM-1 adhesion molecules. ${ }^{32,33}$ To further analyze the inflammatory events that could be involved in the expression of adhesion molecules secondary to venom administration, the release of these eicosanoids into the peritoneal cavity was analyzed. Results showed that i.p. injection of $\mathrm{BjV}$ induced a significant increment in intraperitoneal concentrations of $\mathrm{LTB}_{4}$ and $\mathrm{TXA}_{2}$. These results are in agreement with the previous observations showing the release of eicosanoids into the air pouch injected with $\mathrm{BjV},{ }^{6}$ as well as in the site of injection of venoms from other species of Bothrops genus. ${ }^{4,34}$ Thus, our observations suggest that these mediators may contribute to the expression of ICAM-1 and PECAM-1 induced by $\mathrm{BjV}$. Alternatively, a direct effect of this venom on the endothelium cannot be ruled out. On the other hand, Farsky et al. ${ }^{6,35}$ showed that venoms of Bothrops asper and Bothrops jararaca do not alter the intrinsic mechanisms involved in leukocyte locomotion, in an experimental model in vitro. 
Cytokines have been identified as the key mediators responsible for up-regulation of the expression of adhesion molecules, ${ }^{36}$ and they participate in a variety of inflammatory conditions. ${ }^{37}$ Among them, TNF- $\alpha$, IL- 6 and IL- $1_{\alpha}$ are highly relevant. Elevated concentrations of TNF- $\alpha$ in the peritoneal cavity were detected after i.p. injection of BjV. TNF- $\alpha$ induces the expression of ICAM-1, E-selectin ${ }^{38}$ and CD11b/ CD18. ${ }^{39}$ As a mediator of inflammation, it triggers the release of practically all known mediators such as IL-1, IL-6, IL-8 and all metabolites of arachidonic acid, ${ }^{40,41}$ thereby amplifying the inflammatory cascade. In our experimental model, $\mathrm{TNF}_{-} \alpha$ may be relevant for the expression of ICAM-1 thereby contributing for neutrophil influx. Moreover, release of TNF- $\alpha$ was a longlasting effect following $\mathrm{BjV}$ injection, which suggests that this cytokine may be also important in the activation of leukocytes and production of hydrogen peroxide and nitric oxide observed after venom injection. ${ }^{3}$

IL-6 is also likely to be involved in leukocyte infiltration induced by $\mathrm{BjV}$. The i.p. injection of $\mathrm{BjV}$ induced a significant increment in the concentration of IL-6 in the peritoneal exudates. These results are in concordance with others showing an increase of this cytokine in the serum of mice after i.p. and subcutaneous injection of snake venoms from Bothrops sp. ${ }^{42-44}$

IL-6 is related to the systemic acute phase response associated with infection or injury, including the release of neutrophils into the circulation and the upregulation of ICAM- 1 expression. ${ }^{45}$ Thus, our results suggest that IL- 6 may have a role in the expression of ICAM-1 following BjV injection, being relevant for firm adhesion of neutrophils. Moreover, since maximal production of IL- 6 occurs at $3 \mathrm{~h}$, a time when no release of TNF- $\alpha$ was observed, IL- 6 may also act as a negative mediator of TNF- $\alpha$ production and/or secretion in this experimental model, in agreement with previous observations. ${ }^{44}$ On the other hand, levels of IL- $1_{\alpha}$ were not detectable in our experimental model, in contrast with previous observations describing increments in IL-1 levels in serum of mice after i.p. injection of $\mathrm{BjV}^{44}$ It is likely that non-peritoneal cells are responsible for the production of IL-1 after i.p. injection, resulting in the increments described in serum.

Many cell types produce and secrete inflammatory mediators involved in the leukocyte influx after stimulation. In this way, monocytes and macrophages are the central sources of the studied cytokines and eicosanoids. ${ }^{40}$ Mast cells represent another source of $\mathrm{TNF}_{-} \alpha$ and store this cytokine in specific granules. ${ }^{46}$ Taking into account that $\mathrm{BjV}$ is able to stimulate macrophages and neutrophils, ${ }^{3}$ we assume that these cells, mainly macrophages, are relevant sources of eicosanoids and TNF- $\alpha$ in our experimental model. However, the contribution of mast cells cannot be ruled out, since an earlier release of $\mathrm{TNF}_{-} \alpha$ was detected in the local of $\mathrm{BjV}$ injection. Phospholipase $\mathrm{A}_{2}$-homologues isolated from Botbrops jararacussu venom degranulate mast cells in rats. ${ }^{47}$

In conclusion, we have shown that the neutrophil influx induced by i.p. injection of $\mathrm{BjV}$ venom in mice is related to the expression of LECAM-1, LFA-1, ICAM1, and PECAM-1 adhesion molecules, responsible for the rolling, firm adhesion and transmigration events associated with neutrophil migration. This indicates that the venom is able to induce the expression of adhesion molecules from both leukocytes and endothelial cells. This effect may be indirect, via the release of eicosanoids $\mathrm{LTB}_{4}$ and TXA $\mathrm{T}_{2}$, as well as the cytokines TNF- $\alpha$ and IL-6, but not IL-1.

ACKNOWLEDGEMENTS. The authors thank Dr José Maráa Gutiérrez for the critical review for this manuscript and helpful suggestions, and FAPESP-Brazil for financial support of project (Grants 98/0162-9 and 97/13089-5). The authors wish to acknowledge Dr Nancy Starobinas and Miss Adriana dos Santos Carneiro, Imunogenetic Laboratory, Butantan Institute, for their valuable assistance in performing the $\mathrm{TNF}^{-} \alpha$ assays.

\section{References}

1. Rosenfeld G. Symptomatology, pathology and treatment of snake bites in South America. Venomous Animals and Their Venoms. Academic Press, 1971: 345

2. Trebien HA, Calixto JB. Pharmacological evaluation of rat paw oedema induced by Bothrps jararaca venom. Agents Actions 1989; 26: 292-300.

3. Zamuner SR, Gutiérrez JM, Muscará MN, Teixeira SA, Teixeira CFP. Bothrops asper and Bothrops jararaca snake venoms trigger microbicidal functions of leukocyte in vivo. Toxicon 2001; 39: 505-1513.

4. Flores CA, Zappellini A, Prado-Franceschi J. Lypoxygenase-derived mediators may be involved in in vivo neutrophil migration induced by Bothrops erytromelas and Bothrops alternatus venom. Toxicon 1993; 31: 1551-1559.

5. Acosta de Pérez O, Teibler P, Koscinczuk P, Negrette MS, Trulls H, Maruñak S. Edemay mionecrosis inducidos por veneno de Bothrops jararaca de Argentina en ratones. APPTLA 1996; 46: 233-238.

6. Farsky SHP, Costa-Cruz JWM, Cury Y, Teixeira CFP. Leokocyte response induced by Bothrops jararaca crude venom. In vivo and in vitro studies. Toxicon 1997; 35: 85-93.

7. Konstantopoulos K, McIntire LV. Perspectives series: cell adhesion in vascular biology. J Clin Invest 1997; 11: S19-S23.

8. Arfors KE, Lundberg C, Lindbom L, Lundberg K, Beatty PG, Harlan JM. A monoclonal antibody to the membrane glycoprotein complex CD18 inhibts polymorphonuclear leukocyte accumulation and plasma leakage in vivo. Blood 1987; 69: 338-340.

9. Butcher EC. Leukocyte-endothelial cell recognition-three (or more) steps to specificity and diversity. Cell 1991; 67: 1033-1036.

10. Smith CW, Marlin SD, Rothlein R, Toman C, Anderson DC. Cooperative interactions of LFA-1 and MAC-1 with intercellular adhesion molecule-1 in facilitating adherence and transendothelial migration of human neutrophils in vitro. J Clin Invest 1989; 83: 2008.

11. Christofidou-Solomidou M, Nakada MT, Williams J, Muller WA, DeLisser HM. Neutrophil platelet endothelial cell adhesion molecule-1 participates in neutrophil recruitment at inflammatory sites and is down regulated after leukocyte extravasation. J Immunol 1997; 158 $4872-4878$.

12. Liao F, Huynh HK, Eiroa A, Greene T, Polizzi E, Muller WA. Migration of monocytes across endothelium and passage through extracelullar matrix involved separate molecular domains of PECAM-1. J Exp Med 1995; 182: 1337-1343.

13. Wakelin MW, Sanz MJ, Dewar A, et al. An anti PECAM-1 (CD31) antibody inhibits leukocytes extravasation across mesenteric microvessels in vivo by blocking the passage through the basement membrane. J Exp Med 1996; 184: 229-239.

14. Crocketti-Torabi E. Selectins and mechanisms of sinal transduction. $J$ Leukoc Biol 1998; 63: 1-14.

15. Ridger VC, Wagner BE, Wallace WAH, Hellewell PG. Differential effects of CD18, CD29, and CD49 integrin subunit inhibition on neutrophil migration in pulmonary inflammation. J Imunol 2001; 166: 3484-3490.

16. Scalia R, Armstead VE, Minchenko AG, Lefer AM. Essential role of P-selectin in the initiation of the inflammatory response induced by hemorrage and reinfusion. J Exp Med 1999; 189: 931-938. 
17. Fernandes I, Cormont F, Latinne D, Bazin H, Takehara HA, Mota I. A rapid efficient purification method for horse IgG(T) using a rat monoclonal antibody. Braz J Med Biol Res 1994; 27: 2599-2606.

18. Pradelles P, Grassi J, Maclouf J. Enzyme immunoassays of eicosanoids using acetylcholine esterase as label: an alternative to radioimmunoassay. Anal Chem 1985; 57: 1170-1173.

19. Schumaker JH, O'Garra A, Schrader B, Van Kimmeenade A, Bond MW, Mosmann TR, Coffman RL. The characterization of four monoclonal antibodies specific for mouse IL-5 and development of mouse and human IL-5 ELISA. I Immunol 1988; 141: 1576-1581.

20. Ruff MR, Gifford GE. Purification and phisyco-chemical characterization of rabbit tumor necrosis factor. J Immunol 1980; 125: 1671-1677.

21. Kishimoto TK, Julita MA, Berg EL, Butcher EC. Neutrophil MAC-1 AND mel-14 adhesion protein inversely regulated by chemotactic factors. Science 1989; 245: 1238-1241.

22. Ley K, Bullard DC, Arbones ML, Bosse R, Vestweber D, Tedder TF, Beaudet AL. Sequential contribution of L- and P-selectin to leukocyte rolling in vivo. J Exp Med 1995; 181: 669-675.

23. Von Adrian UH, Hansell P, Chambers JD, Berger EM, Filho IT, Butcher EC, Arfors KE. L-selectin functions is required dor B2 integrin-mediated neutrophil adhesion at physiologic shear rates in vivo. Am J Physiol 1992; 263: H1034-H1044.

24. Dobrina A, Schwartz BR, Carlos TM, Ochs HD, Beatty PG, Harlan JM CD11/CD18-independent neutrophil adherence to inducible endothelialleucocyte adhesion molecules (E-LAM) in vitro. Immunology 1989; 67: 502-508.

25. Geng J, Bevilacqua MP, Moore KL, et al. Rapid neutrophil adhesion to activated endothelium mediated by GMP-140. Nature 1990; 343:

26. Hellewell PG, Yong SK, Henson PM, Worthen GS. Disparate role of the beta 2-integrin CD18 in the local accumulation of neutrophils in pulmonary and cutaneous inflammation in the rabbit. Am J Respir Cell Mol Biol 1994; 10: 391-398.

27. Morland CM, Morland BJ, Darbyshire PJ, Stockley RA. Migration of CD18deficient neutrophils in vitro: evidence for a CD18-independent pathway induced by IL-8. Biochem Biophys Acta 2000; 1500: 70-76.

28. Winn RK, Harlan JM. CD18-independent neutrophil and mononuclear leukocyte emigration into the peritoneum of rabbits. J Clin Invest 1993 ; 92: 1168-1173.

29. Steeber DA, Tang NLK, Green NE, Zhang XQ, Sloane JE, Tedder TF. Leukocyte entry into sites of inflammation requires overlapping interactions between the L-selectin and ICAM-1 pathways. J Immunol 1999; 163: 2176-2186.

30. Entman ML, Youker K, Shoji T, Kukielka G, Shappell SB, Taylor AA, Smith CV. Neutrophil induces oxidative injury of cardiac myocites. A compartmented system requiring CD11B/CD18-ICAM-1 adherence. J Clin Invest 1992; 90: 1335-1345.

31. Sun J, Paddock C, Shubert J, Zhang HB, Amin K, Newman PJ, Albelda SM. Contributions of the extracellular and cytoplasmic domains of plateletendothelial cell adhesion molecule-1 (PECAM-1/CD31) in regulating cell-cell localization. J. Cell Science 2000; 113: 1459-1469.
32. Wiles ME, Welborn R, Goldman G, Hechtman HB, Shepro D. Tromboxane-induced neutrophil adhesion to pulmonary microvascular and aortic endothelium is regulated by CD18. Inflammation 1991; 15: 181-197.

33. Caughey GE, Pouliot M, Cleland LG, James MJ. Regulation of tumor necrosis factor- $\alpha$ and IL- $1 \beta$ synthesis by Thromboxane $A_{2}$ in nonadherent human monocytes. J Immunol 1997; 158: 351-358.

34. Búrigo AC, Calixto JB, Medeiros YS. Pharmacological profile of rat pleurisy induced by Bothrops jararaca venom. J Pharmacol 1996; 48: 106-111.

35. Farsky SH, Gon alves LR, Gutiérrez JM, Correa AP, Rucavado A, Tambourgi DV. Bothrops asper snake venom and its metalloproteinase $\mathrm{BaP}-1$ activate the complement system. Role in leukocyte recruitment. Mediators Inflamm 2000; 9: 213-221.

36. Pober JS. Effects of tumor necrosis factor and related cytokines on vascular endothelial cells. Ciba Found Symp 1987; 131: 170-184.

37. Dinarello CA. The proinflammatory cytokines interleukin-1 and tumor necrosis factor and treatments of the shock syndrome. J Infect Dis 1991; 163: $1177-1183$.

38. Sharp C, Warren A, Oshima T, Willians L, Li JH, Alexander JS. Poly ADP ribose-polymerase inhibitors prevent the upregularion of ICAM-1 and E-selectin in response to Th1 cytokine stimulation. Inflammation 2001; 25: 57-163.

39. Miyata R, Iwabuchi K, Watanabe S, Sato N, Nagaoka I. Short exposure of intestinal epithelial cells to TNF- $\alpha$ and histamine induces MAC-1 mediated neutrophil adhesion independent of protein synthesis. $J$ Leukoc Biol 1999; 66: 437-446.

40. Vassali P. The pathophysiology of tumor necrosis factors Annu Rev Immunol 1992; 10: 411-452.

41. Paludan SR. Synergistic action of pro-inflammatory agents: cellular and molecular aspect. J Leukoc Biol 2000; 67: 18-25.

42. Lomonte B, Tarkowski A, Hanson LA. Host response to Bothrops asper snake venom. Inflammation 1993; 17: 93-105.

43. Barros SF, Friedlanskaia I, Petricevich VL, Kipnis TL. Local inflammation, lethality and cytokine release in mice injected with Bothrops atrox venom. Mediators Inflamm 1998; 7: 339-346.

44. Petricevich VL, Teixeira CFP, Tambourgi DV, Gutiérrez JM. Increments in cytokine and nitric oxide serum levels in mice injected with Bothrops asper and Bothrops jararaca snake venoms. Toxicon 2000; 38 : 1253-1266.

45. Tilg H, Dinarello CA, Mier JW. IL-6 and PPAs: anti-inflammatory and immunosupressive mediators. Immunol Today 1997; 18: 428-432.

46. Gordon JR, Burd PR, Galli SJ. Mast cell as a source of multifuncional cytokines. Immunol Today 1990; 11: 458-464.

47. Landucci ECT, Castro RC, Pereira MF, et al. Mast cell degranulation induced by two phospholipase $\mathrm{A}_{2}$ homologues: dissociation between enzymatic and biological activities. Eur J Pharmacol 1998; 343: $257-263$.

Received 26 August 2002

Accepted 3 October 2002 


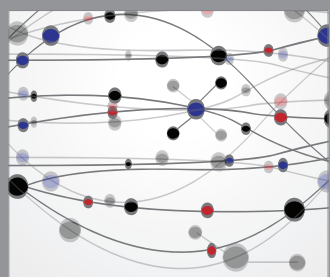

The Scientific World Journal




Gastroenterology

Research and Practice
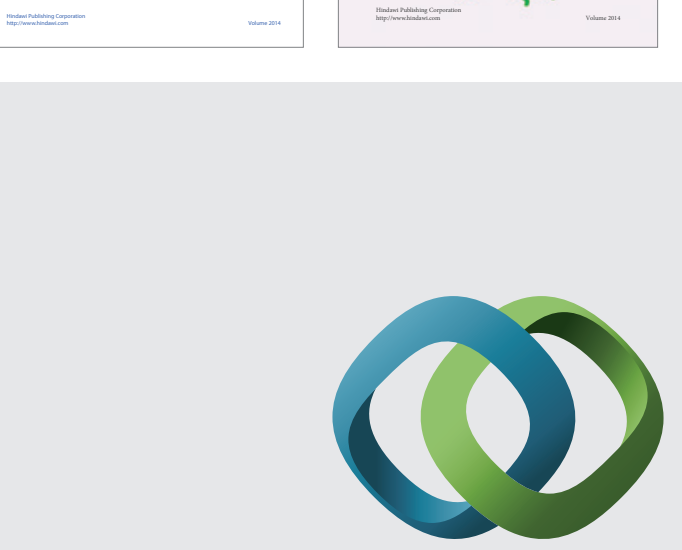

\section{Hindawi}

Submit your manuscripts at

http://www.hindawi.com
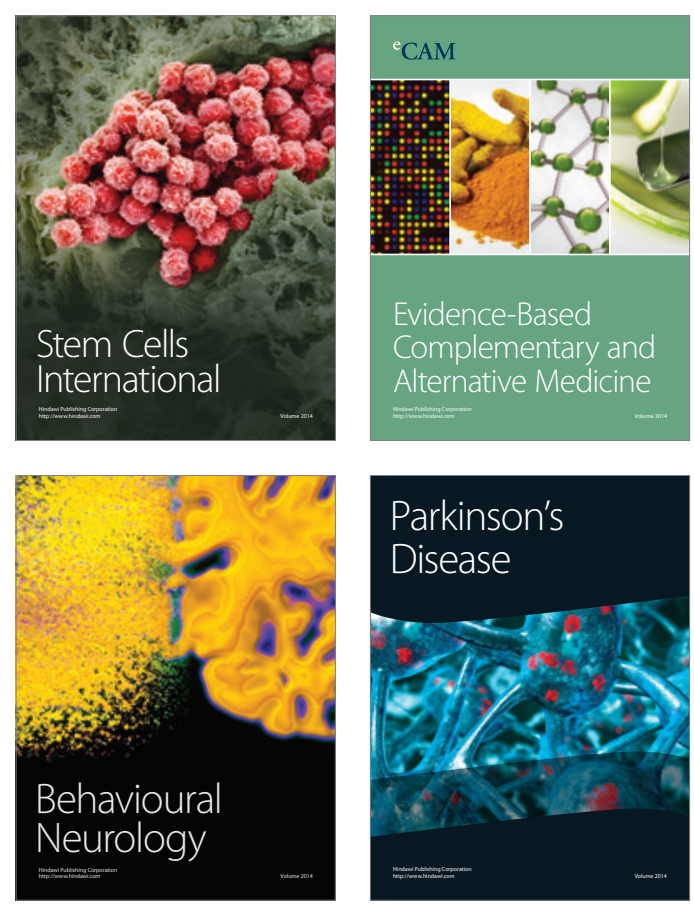

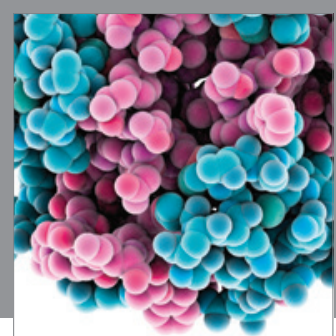

Journal of
Diabetes Research

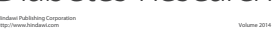

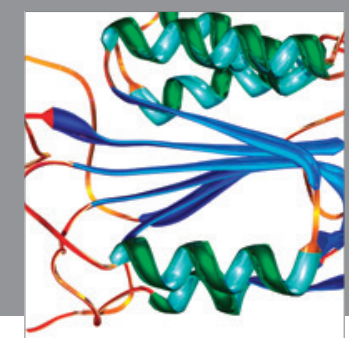

Disease Markers
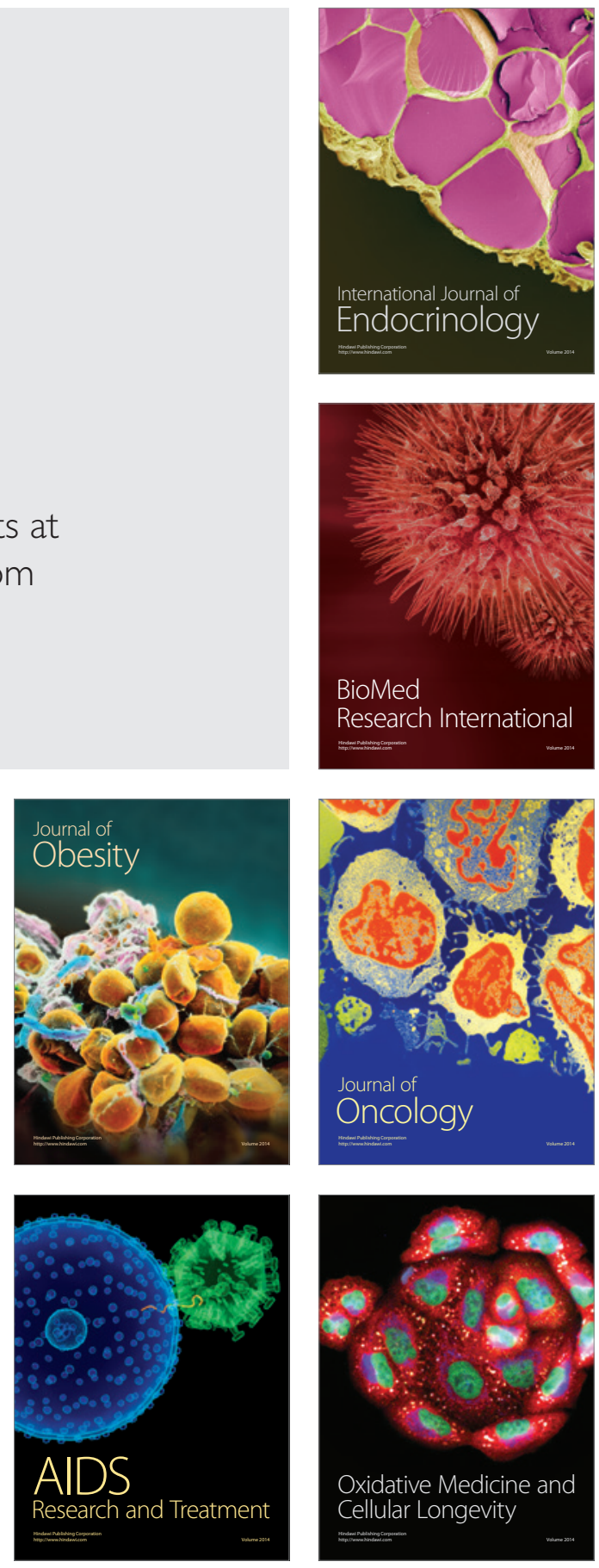